Vol. 4, No. 02; 2021

ISSN: 2581-4664

\title{
ASSESSMENT OF NON-NURSINGTASKS/ACTIVITIES INDUCE WORKLOAD IN GOVERNMENT HOSPITALS
}

\author{
Wasfi Dhahirabid Ali, Luay Abdulwahidshihab and Farhan I.L \\ Department of basic sciences - college of nursing- University of Basrah -Iraq \\ http://doi.org/10.35409/IJBMER.2021.3244
}

\begin{abstract}
This study conducted and thirty nurses were respond to assess the non- nursing tasks the effect the quality of nursing care provided to hospitalized patients The demographic information of the present study showed that nurses participated aged between 26-35 year (46\%) and most of them married (70\%),the gender (72.4) were female, most of them have work experience 11 years while $43.3 \%$ have diplomate (two year study after secondary education four year and the normal weekly hours working. on other hand On the other hand, the results of the study showed the significance mean of score of assigning nurses to non-nursing tasks in hospitals.
\end{abstract}

Keyword: Nurses.Conditions, Hospitals.

\section{INTRODUCTION}

The patient is the first priority of the nurse. The role of the nurse is to advocate for the best interests of the patient and to maintain the patient's dignity throughout treatment and care. This may include making suggestions in the treatment plan of patients, in collaboration with other health professionals. The theme of lack of control ran through the nurses' accounts of work overload. To retain nurses, employers need to allow nurses some control over their workload and some time to include in their nursing the things they enjoy the most.(Alice, 2002). The demand for nurses is increasing as a result of population aging. Between 2000 and 2020, the United States population is expected to grow by 18 percent $(31$ million), but the over-65 population, with more health care needs, is expected to grow by 54 percent (19 million)(General Accounting Office2001), and the workload increases for those who remain on the job(Baumann , et al.,2001). Griffithet al.,1999) pointed that a heavy nursing workload can influence the care provider's decision to perform various procedures.

Previous research provides strong evidence that high nursing workloads at the unit level have a negative impact on patient outcomes.7,12,13 These studies' suggestions regarding improving patient care are limited to increasing the number of nurses in a unit or decreasing the number of patients assigned to each nurse(Needleman et al.,2002, Amaravadiet al .,2000, Langetal.,2004).

Nursing workload definitely affects the time that a nurse can allot to various tasks. Under a heavy workload, nurses may not have sufficient time to perform tasks that can have a direct effect on patient safety. A heavy nursing workload can influence the care provider's decision to perform various procedures (Llenore and Ogle 1999). Unfinished care has a strong relationship 


\section{International Journal of Business Management and Economic Review}

Vol. 4, No. 02; 2021

ISSN: 2581-4664

with quality of nursing care. Over $40 \%$ of the variations in quality ratingsare associated with the number of tasks left undone(Sochalski 2004). Nurses working under the pressure of inadequate time and frequent interruptions try to catch up time by minimizing the time spent on required tasks and redefine work responsibilities to complete the tasks they are accountable for, which often interfere with providing high qualitycare (Bowers et al. 2001), Contamination occurs everywhere including environment and all its objects. Computer s keyboards and mice are the most open surface parts of computer which show $100 \%$ contamination. This study has demonstrated that microbial contamination of multiple-user computer keyboards may be a common mechanismof transfer of potentially pathogenic bacteria among users, computers continue to Khulood Abdul Kareem, Luaay Abdul WahedShihab, et al ( 2016) .

\section{METHODOLOGY}

A descriptive-analytical cross-sectional study was used to assess the nurses working conditions at different departments at governmental hospitals in Basra government . The study establishing to assess the most effective conditions in the nurse daily work(non nursing tasks) .The study was conducted at many departments at general governmental hospitals at the main general governmental hospitals in Basrah governorate .The sample of this study was consisting of all nursing staff, head nurses and supervisor, data collected via google form include personal Demographic questions as well as questions regarding non-nursing tasks/activities. The sample size was (30)nurses who participated in the study with a response .frequency, percentage, mean of score and significant were calculated.

\section{RESULTS AND DISCUSSION}

Table(1) The frequents an percentage of nurses demographic information $(\mathrm{N}=30)$

\begin{tabular}{|c|l|l|l|}
\hline \multirow{4}{*}{ age } & & $\mathrm{F}$ & $\%$ \\
\cline { 2 - 4 } & $18-25$ & 7 & 23.3 \\
\cline { 2 - 4 } & $26-35$ & 14 & 46.7 \\
\cline { 2 - 4 } & 36 -over & 9 & 30 \\
\hline \multirow{2}{*}{ marital status } & Married & 21 & 70 \\
\cline { 2 - 4 } & Single & 9 & 30 \\
\hline \multirow{2}{*}{ Qualification } & Male & 9 & 27.6 \\
\cline { 2 - 4 } & Female & 21 & 72.4 \\
\cline { 2 - 4 } & BSc. & 9 & 26.7 \\
\cline { 2 - 4 } & Diplomate & 13 & 43.3 \\
\hline \multirow{3}{*}{ Years of } & Secondary & 8 & 30 \\
\hline \multirow{3}{*}{ working in hospital } & 5 & 11 & 36.7 \\
\cline { 2 - 4 } & 6year month- & & \\
\cline { 2 - 4 } & $6-15$ year & 11 & 36.7 \\
\cline { 2 - 4 } & 16 -over & 8 & 26.7 \\
\hline Weekly work hrs & 30hr. & 19 & 65.7 \\
\hline
\end{tabular}




\section{International Journal of Business Management and Economic Review}

Vol. 4, No. 02; 2021

ISSN: $2581-4664$

\begin{tabular}{|l|l|l|}
\hline $45 \mathrm{hr}$. & & 30 \\
\hline & & \\
\hline
\end{tabular}

Non nursing tasks care has a strong relationship with quality of nursing care given for patients as nurses play various non-nursing roles, below, above and in the horizontal levels, both inside and outside other healthcare professionals' role, mainly as a result of their felt moral obligation to offer the best to their patients, the organization's demand to nurses and the imprinting of nursing education.

Most participants nurse on this study aged (26-35 year), while their education were diplomate ( two year after four year of secondary school), Fatimah and Deepa (2009) in their study to assess the workload of nurses showed that nurses' age and educational background influenced task completion while nurses' gender had no influence on it. Increased patient loads, resulting in increased frequency of nursing tasks and non-nursing tasks, were positively correlated to incompletion of nursing activities.

Table (2) Frequents and percentage of questions regarding non-nursing tasks/ activities

\begin{tabular}{|c|c|c|c|c|c|c|}
\hline \multirow{2}{*}{$\begin{array}{l}\text { Non-nursing tasks/ } \\
\text { activities }\end{array}$} & \multicolumn{2}{|c|}{ Yes } & \multicolumn{2}{|c|}{ NO } & \multirow{2}{*}{$\begin{array}{l}\mathbf{M} \\
\mathbf{S}\end{array}$} & \multirow[t]{2}{*}{$\mathbf{S}$} \\
\hline & $\mathrm{F}$ & $\%$ & $\mathrm{~F}$ & $\%$ & & \\
\hline Clerical work -general & 23 & 76.7 & 7 & 23.3 & $\begin{array}{c}1 . \\
59\end{array}$ & $\mathrm{~S}$ \\
\hline $\begin{array}{l}\text { administrative work } \\
\text { separating nurses from } \\
\text { patients. }\end{array}$ & 19 & 63.3 & 11 & 36.7 & 63 & $\mathrm{~S}$ \\
\hline $\begin{array}{l}\text { Full-time for nursing } \\
\text { assignments only }\end{array}$ & 18 & 60 & 12 & 40 & 1. & $\mathrm{~S}$ \\
\hline Transfer & 28 & 93.3 & 2 & 6.7 & 93. & $\mathrm{~S}$ \\
\hline referrals & 22 & 73.3 & 8 & 26.7 & 73 & $\mathrm{~S}$ \\
\hline Transporting patients & 16 & 55.2 & 14 & 44.8 & 53 & $\mathrm{~S}$ \\
\hline $\begin{array}{l}\text { General house keeping } \\
\text { such as indent for store, } \\
\text { maintenance, } \\
\text { electric./plump }\end{array}$ & 17 & 56.7 & 13 & 43.3 & $\begin{array}{c}1 . \\
56\end{array}$ & $\mathrm{~S}$ \\
\hline Receiving linen & 19 & 63.3 & 11 & 36.7 & 63 & $\mathrm{~S}$ \\
\hline $\begin{array}{l}\text { Delivering / retrieving } \\
\text { food trays }\end{array}$ & 3 & 10 & 27 & 90 & 11. & $\mathrm{~S}^{\mathrm{N}}$ \\
\hline Ordering ,coordinating & 17 & 56.7 & 13 & 43.3 & 1. & $\mathrm{~S}$ \\
\hline
\end{tabular}




\section{International Journal of Business Management and Economic Review}

Vol. 4, No. 02; 2021

ISSN: 2581-4664

\begin{tabular}{|l|c|c|c|c|c|c|}
\hline \hline $\begin{array}{l}\text { and preforming ancillary } \\
\text { services }\end{array}$ & & & & 56 & \\
\hline $\begin{array}{l}\text { Other duties such as } \\
\text { receiving pharmacy or } \\
\text { arranging for ambulance }\end{array}$ & 13 & 43.3 & 17 & 56.6 & 1. & $\mathrm{~N}$ \\
\hline
\end{tabular}

According to the International council of nurses, nursing is to care for individuals in an autonomous and collaborative manner whether sick or well. It is to promote health, prevent illness, to care for the ill, the disabled and the dying. Nursing includes being an advocate, to promote safe environments, to do research, to help with health policy shaping and management and lastly to educate(Claudia et al., 2010) .

Grossoet al., (2019)concluded that nurses play various non-nursing roles, below, above and in the horizontal levels, both inside and outside other healthcare professionals' role, mainly as a result of their felt moral obligation to offer the best to their patients, the organization's demand to nurses and the imprinting of nursing education and antecedents of 'Being out of the nursing role'.

Bekker (2013)stated that the relationship between non-nursing tasks (NNTs), nursing tasks left undone (NTLU), and internationally it was found that these factors have an effect on job satisfaction and he found the there were three main NNTs performed were filling-in for nonnursing services, cleaning patient's rooms and equipment and obtaining supplies and equipment and nationally more than $50 \%$ of PNs reported the following NTLU .

Deliveringand retrieving food trays, housekeeping duties, transportingpatients and ordering, coordinating, or performing ancillarytests .Kiekkaset al. (2005) found that nursesspent only 35 $.2 \%$ of their time on direct clinical care.

We suggest the non-nursing work distracts the work strategy of the nurse to provide the necessary care to the patient and weakens his ability to concentrate in the performance of his nursing mission.as (Grosso et al.,2019)that nurse administrators who listen to nurses' experience of workload may be able to find strategies to help nurses deal with their workload.

Pillay (2009) compared job satisfaction levels of nurses in private and public hospitals. in the private sector proved to be more satisfied than those in the public sector, who were generally dissatisfied with their jobs. The private sector had better resources than those in the public sector - for instance available and working equipment, time, medication and staff. These factors lead to more efficient and effective health care, which sees the patients as priority and ensures that their needs are met.

\section{CONCLUSION}

The present study concluded thenegatively significant effect of all non-nursing activities (Clerical work -general, administrative work separating nurses from patients. Full-time for nursing assignments only, Transfer, referrals, Transporting patients, General house keeping such as indent for store, maintenance, electric./plump, Receiving linen. coordinating and preforming ancillary services), exceptDelivering /retrieving food trays Ordering and other duties such as receiving pharmacy or arranging for ambulance) 
Vol. 4, No. 02; 2021

ISSN: 2581-4664

\section{REFERENCES}

Aiken L, Sochalski J, Anderson G.)1996( Downsizing the hospital nursing workforce. Health Aff.; 15:88-92.

Alice P Gaudine (2002)What do Nurses Mean by Workload and Work Overload?Canadian Journal of Nursing Leadership 13(2):22-7.

Amaravadi RK, Dimick JB, Pronovost PJ, et al.(2000) ICU nurse-to-patient ratio is associated with complications and resource use after esophagectomy. Intensive Care Med. 26(12): 1857-62.

Baumann A, Giovannetti P, O'Brien-Pallas L, et al. (2001)Healthcare restructuring: the impact of job change. Can J NursLeadersh. 14:14-20.

Bekker, MC.(2013)The relationship between non-nursingtasks, nursing tasks left undone and jobsatisfaction among professional nurses inSouth African hospitalsDissertation submitted in fulfillment of the requirements for thedegree Magister Curationisin Nursing Science at the Potchefstroom Campus of the North-West University20710798.

Bowers BJ, Lauring C \& Jacobson N (2001) How nurses managetime and work in long-term care. Journal of Advanced Nursing 33, 484-491.

Claudia C. Bartz, PhD, RN, FAANI .(2010)nternational Council of Nurses and person-centered care .IntJ Integr Care.; 10(Suppl): e010.

Fatimah Al-Kandari and Deepa Thomas.(2009)Factors contributing to nursing task incompletion as perceived by nurses working in Kuwait general hospitals of Clinical Nursing 18(24):3430-40.

General Accounting Office.(2001) Nursing workforce-recruitment and retention of nurses and nurse aides is a growing concern. Washington, DC: United States General Accounting Office; No. GAO-01-750T.

Griffith CH, Wilson JF, Desai NS, et al. (1999)Housestaff workload and procedure frequency in the neonatal intensive care unit. Crit Care Med. 27:815-20.

Grosso S, S Tonet, Bernard, J Corso, D De Marchi, L Dorigo, G Funes, M Lussu, N Oppio, L Pais Dei Mori, A Palese.(2019)Non-nursing tasks asexperienced by nurses: a descriptive qualitative study.IntNursRev Jun;66(2):259-268.

Kiekkas P, Poulopoulou M, Papahatzi A, Androutsopoulou C,Maliouki M \&Prinou A (2005) Nursing activities and use of timein the postanesthesia care unit. Journal of PerianesthesiaNursing ;20, 311-322.

Lang TA, Hodge M, Olson V, et al.(2004) Nurse-patient ratios: a systematic review on the effects of nurse staffing on patient, nurse employee, and hospital outcomes. J Nurs Adm. 34(7-8):326-37.

Khulood Abdul Kareem, Luaay Abdul WahedShihab, et al .( 2016) Genetic Study for icaAD Gene to Staphylococcus Aureus Isolated from Different Part of Computer, International Journal of Advanced Research in Computer Science and Software Engineering, Volume 6, Issue 1, January 2016.

Lenore E, Ogle KR.(1999) Nurse-patient communication in the intensive care unit: a review of the literature. AustCrit Care. 12(4):142-5.

Needleman J, Buerhaus P, Mattke S, et al. (2002)Nurse-staffing levels and the quality of care in hospitals. N Engl J Med. 346(22):1715-22 
International Journal of Business Management and Economic Review

Vol. 4, No. 02; 2021

ISSN: 2581-4664

Pillay, Y., McCoy, D. \& Asia, B. 2001. The district health system in South Africa: progress made and next steps. Pretoria: National Department of Health.

Sochalski J (2004) Is more better?: the relationship betweennurse staffing and the quality of nursing care in hospitals. Medical Care 42. 